\section{Liliya TSYGANENKO}

Izmail State Liberal Arts University, Izmail (Ukraine)
SOUTHERN UKRAINE NOBILITY'S ETHNIC STRUCTURE

(LATE $18^{\text {TH }}-$ EARLY 19 ${ }^{\text {TH }}$ CENTURIES)

(2)
Ключевые слова: дворянство, колонизаџия, общероссийская перепись населения, этнические группь, аристократы, иляхта.
Цыганенко Лилия. Этническая структура дворянства Юга Украины (конец XVIII - XIX Bв.) (2)

Анализируется этнический состав дворянства Екатеринославской, Херсонской и Бессарабской губерний; участие аристократов украинского, русского, молдавского, греческого, итальянского, немецкого происхождения в процессах колонизации и освоения южноукраинских земель Российской империи в конце XVIII- XIX вв.
In the second half of the XVIII - early of the XIX cent. the ranks of the southern ukrainian nobility considerably enriched by the immigrants from the Danube princedoms Moldavia and Wallachia. At the initial stage of the colonization of the region the moldavians (in this case we understand and moldavians and volokhs) were one of the numerous groups of the foreign immigrants.

The author considers that there were three waves of the moldavian migration to the ukrainian provinces during the XVIII cent. The first wave of the resettlements of the representatives of the moldovian ethnic group associated with the failure Pruth campaign under the command Peter I in 1711, when the russian nationality accepted 24 families of the boyars with the moldavian proprietor D. Cantemir. Their settlements were mainly in Slobozhanshina, where they received 710 courts ${ }^{1}$.

Since the middle of the XVIII cent. begins the second wave of the moldavian migration in the southern ukrainian lands, in which the representatives of the moldavian boyars were directly involved. Thus, in 1752 there was the moldavian boyar Manolakiy Zamfirakovych in New Serbia. The lieutenant M. Fuharov, the regimental commissar P. Wind served in Slov'yanoserbia. According to A. Skalkovskiy, in 1753 Vasily Zverev, moldovan by origin, whose real name was Vasile Lupul, actively participated in establishing Novokozachiy regiment, having moved more than thousand peasants in the southern ukrainian lands from which were formed companies of the military-agricultural settlements ${ }^{2}$. The third wave of the migration of the moldovan boyars took place in 90-th of the XVIII cent. when Russia, preparing the accession of Bessarabia, encourage them to dwell on their territories.

The late of the XVIII cent. among the landowners of Katerynoslavs'ka province we meet the representatives of the moldovian aristocracy - the owner Rosseti (12.000 des. land), actual secret adviser of the prince Kantakuzino (12.000 des.), the prince Pervula Kantakuzino (6.000 des.), the princess Roksandra Hiku (9,000 Des.), the generalmajor V. Zverev (Lupul) (12.477 des. of the land). At the same time in Tiraspol district there were twenty-six the moldavian boyars, the total area of land given to them amounted to 251.535 des. ${ }^{3}$. After 1812 the flow of the moldovian migrants to Katerynoslavs'ka and Khersons'ka provinces practically disappears. This is largely due to the inclusion of Bessarabia into the Russian Empire.

If earlier in Katerynoslavs'ka and Khersons'ka provinces the moldavian nobility acted as the immigrants and "the desired element", then the annexation of Bessarabia, where most land is owned by the moldavian 
boyars, there is the change in the relations between the government and the moldavian aristocracy. Now is not the Russian government, and the boyars were interested in establishing "friendly relations" with the authorities, in order to preserve their status, ground possessions, class privileges.

In the early of the XIX cent. there was the stable, albeit poorly consolidated, but the material provided and politically influential group of privileged people in Bessarabia, which consisted of the boyars and boyarynashi ${ }^{4}$. After the accession of Bessarabia to the Russian Empire the local aristocracy tried to take the adequate part in the management of the land. The first civilian governor of the region were assigned S. Sturdza, who for the moldovian gradation had the rank of the vellohofet. His successors from the local representatives were the general Hartynh, the governor Katakazi.

In the 1816-1817 according to the facts of A. Krupenskiy the number of the moldavian boyars who received the russian citizenship made 46 persons. In addition, there is the protocol of one of the first meeting of the boyars and noblemen of the land in our disposal, signed by 52 persons ${ }^{5}$.

What do the tiny (compared to the total number) number of the moldavian nobility mean? At first sight, that the representatives of some 50 moldovian boyar families included the part of the Russian nobility of Bessarabia only during one year. While on the other side in Bessarabia two years after joining the Russian Empire there were many representatives of the moldavian aristocratic families, who did not rush to take the russian citizenship, especially as we find among others the well-known surnames in the province, as Bashta, Donichi, Katarzhyu, Ryshkany and others. According to "Statistical review of $1822-1828$ ", for 1827 more than 2.000 persons (from 112722) represents the moldovian boyars and boyarynashi, at that time were held the process of the incorporation to the higher status of the Russian Empire.

The moldavian as origin nobility of Bessarabs'ka province in the second half of the XIX - early of the XX cent. is not different from the nobility of other Russian provinces. It finally lost the legal distinctions in their status, having full procedure of the incorporation to the status of the Russian nobility. If in 20-th of the XIX cent. more than $90 \%$ of the bessarabian nobility - the moldavian nobility, by the middle of the century, its number is reduced to $70 \%$. Thus there is an increase of the noblemen - the representatives of other ethnic groups.

The materials for All-russian census show, that the number of the noblemen of the moldavian roots in three Black Sea provinces was more than 4,5 thousand persons, representing almost $5 \%$ of the mass of the nobility. The smallest number of the noblemen from the moldovans lived in Katerinoslavs'ka province - at the end of the XIX cent. their total number was no more than 30 persons. And in spite of the fact Katerynoslavschyna was among the first in which the moldovan immigrants began to arrive. Something more was the number of the noblemen - ethnic moldovans in Khersons'ka province -326 persons $(0,64 \%)$. Historically justified by the number of the moldovian element among the nobility of the province was Bessarabs'ka - the total number of the noblemen - moldovans here was 4281 person, that there was one fifth part of the land in the total number of the nobility.

Acknowledgement of the information of the number of the nobility of the moldavian roots in the bessarabian lands was the facts contained in the genealogical book of the bessarabian nobility. The first part of the book, which were, as a rule, the descendants of the nobility from the areas linked to Russia, was made 113 persons, of which about 70 are the representatives of the moldovan aristocracy. Among the most famous surnames of the part of the book were Alexandry, Buzny, Donika-Iordakesko, Ziloti, Kazimir, Casso, Lazo, Leonard, Nour, Rosset, Sturdza, Feodosia, Yamandi and etc.

The moldavian families were not revealed in the second part of the genealogical book of Bessarabs'ka province, which represents the military nobility but in the third part of the book (receiving the nobility through the state service) there were the considerable part the introduced surnames belongs to the representatives of the moldavian ethnic - K. Bodesko, 
I. Botezat, K. Ballas, A. Doks, S. Dunka, O. Kotrutsa, G. Katakazi and M. Katakazi, L. Nyaha, M. Puryshkevych, S. Rally, K. Stamati and etc.

Concerning to the fourth category, which belonged to the foreign noble families, in Bessarabia there were very little - four surnames $(1,1 \%$ of the hereditary noblemen, made in the genealogical books): K. Andriyanov, A. Botyan, I. Erzhiu, O. Drahichevych-Nikitich. The first three were natives from the moldavian princedoms. In the fifth titled - part of the noble genealogical book of Bessarabia there was included only six surnames, among them the moldavian princes Kantakuziny, Moruzi, the barons Roseny and Stuarty. Exactly half of the surnames (44 of 88) belonged to the noblemen of the moldavian roots in the sixth part of genealogical books, which made the representatives of the old families of the nobility Balshi, Gagariny-Sturdzy, Donichi, Christ, Katarzhy, Rousseau, Rally, Rosseti, Stroesko and others. Thus, the proofs on the nobility of Matvia and Peter Donich come to 1609; Nicholas, Fedor and George Krupensky - to 1678; Nicholas and Peter Katarzhy - to 1630; the representatives of the family Rousseau to 1617; Rosset - to 1714; Ivan and Stroesko - to 1682 ; Iason Yatsymyrskiy $-1663^{6}$.

To the updated lists of the noble families of Bessarabs'ka province was already submitted 468 surnames for 1911. Their big part, more than $70 \%$ belonged to the local inhabitants: 198 families from Bessarabs'ka region, which of 139 came from the nobility of the moldavian princedom.

Historically it happened that the moldavian nobility took the greater impact on the development of Bessarabs'ka province. It was possible to realize the important steps to improve the management in the province, to strengthen the position of the noble stratum in general thanks to the bessarabian nobility.

The materials of the summary facts of the First All-russian census in 1897 allowed the author to compare the number among the nobility of the southern ukrainian provinces of the representatives of other ethnic groups who participated in the processes of the colonization and exploration of the Black Sea and Danube lands. Generally, except the russian, ukrainian, polish, moldavian noblemen, the noblemen - the representatives of 22 ethnic groups among them to pass the $1 \%$ barrier it was possible only the german noblemen have been made in the noble genealogical books of Bessarabs'ka, Katerynoslavs'ka and Khersons'ka provinces.

The late of the XVIII cent. the first german settlers appear in Katerynoslavs'ka province. From 1803 to 180931 german settlements was founded in Khersons'ka province. The immigration of the germans to the territory Katerynoslavs'ka and Khersons'ka provinces continued to the middle 30th of the XIX cent., after that the movement went into decline. The Germans appear in Bessarabia in 1815. One of the largest settlements on these lands became the colony Sarata. The authority successfully used a socalled recruiters, who organized the departure of the colonists to Russia to encourage the resettlement of germans in the Black Sea lands. One of the famous german recruiters was the baron Ferdinand de Cano de Borehard.

And even among the german settlers in the southern ukrainian lands the overwhelming majority (more than 60\%) were the peasants and artisans, however, and the representatives of the german nobility did not remain aloof from the prospect of the new lands in the New Russia. Most german aristocrats lived in the southern ukrainian provinces on the rights of the private owners, but not the colonists.

The prominent figures of the southern ukrainian provinces we can name the family Faltz-Fein, who became famous for the foundation the reserve Ascania-Nova, the prominent scientist-archaeologist E. fon Shtern, the founder of the first kindergarten in the city the baroness Meyendorf, the baron Frideburh - better known as a actor Miloslavsky (died in 1882 during the performance on the stage). The german baron Hintseburh E. G. was the founder the discount bank in Odessa, it was considered as one of the best financiers in Russia. His fortune, which he received from the estates in Taurian province, bequeathed to charitable affairs of the city. The inhabitants of the region were the german aristocrats the general from the artillery the count Dmitry Yerofiyovych Austen-Saken (1789-1881), the 
organizer and the leader of the defense of Odessa during the Crimean War (1854), the chief military of the region of Bessarabs'ka and Khersons'ka province); the generallieutenant, the baron F. fon Meyendorf - the assistant of the chief of the provincial chancery ${ }^{7}$.

According to the census of 1897 the total number of the noblemen-germans in three southern ukrainian provinces was 1249 people or nearly $1.5 \%$ of the total number of this stratum in the region. Most of the german aristocracy settled in the lands of Khersons'ka province and especially in Odessa. The german noble community in Katerynoslavs'ka and Bessarabs'ka land were almost equal in number. Their number in these provinces barely exceeded $1 \%$.

The remaining members of the ethnic minorities among the mass of the nobility of the southern ukrainian provinces by their number did not reach $1 \%$ of the total number of the noblemen of the provinces. However, in the opinion of the author, the small number of these groups does not mean that their presence for the region remained completely invisible. Moreover, there is very interesting and even special among the small number of the noble ethnic community.

Take for example the Jewish nobility. The question about the right of the jews on the noble status - one of the interesting contradictions in the russian society and law. In general, the jewish nobleman in the tsarist Russia was a paradoxical phenomenon. On the one hand, the status of the nobleman designates the presence of the higher class privilege, on the other - the status of the jews meant the minimum of the available right. For the accurate statement of the researcher $\mathrm{S}$. Becker, it is less the rights than a jew, had only a convicted villain ${ }^{8}$. It is impossible to forget about the so-called "The strip of the settlement" for the jewish population of the Russian Empire.

However, according to the First all-russian census of 1897, 108 hereditary noblemen of the jewish origin have been fixed in 50 provinces. For the southern ukrainian provinces there was not any the nobleman-jew in Bessarabia and in Katerynoslav, but 13 hereditary noblemen-jews, lived in Kherson,
10 of them - in Odesa ${ }^{9}$. Although the part of the noblemen-jews was scanty in the scales of the multimillion empire's population, this phenomenon requires an explanation.

Before the 60-th of XIX cent. there were virtually no cases, where the jews had the noble status. Alexander I was the first russian tsar, who gave the partial access to the state and officer service to the jews: in the presence medical or other university education the jews could be accepted for the service, obtaining under the enrollment the ranks from the eighth to the tenth class, which gave its owner the personal status of the nobleman. The jews - the personal nobleman had to reach the ranks of the actual state councilor or receive the order of St. Vladimir IV degree (in 1900) for to obtain the status of the hereditary nobleman. That is the way - through the state service - the majority of the jews received their privileged status in the late of the XIX cent. However, even the scanty number of the noblemen-jews caused anxiety both from government and from the noble community. From 1898 to 1901, it was issued several decrees of the Senate concerning the noblemen-jews, all of them had the inhibitory character.

Another observation that also allows to explain the stated number of the jews - the hereditary noblemen in Odessa: 6 of 13 the hereditary noblemen-jews - they were women. This means that their status they can get through the marriage.

Thus, the majority of the noblemen - jews had the especial status, and they got it only through the education and the state activity. Moreover, the objective conditions of the southern ukrainian provinces (acute need for skilled personnel, the numerous vacancies at all levels of the city and provincial authorities) opened before the representatives of this ethnic group opportunities of placing in a job and further promotions.

Unimportant quantitatively, but quite the significant group of the mass of the nobility of the southern ukrainian lands made the armenians and georgians. They carried their service traditionally in the hussar troops of the russian army.

We meet among the famous landowners of the southern land the second major the prince 
Manvelov, the captains E. Kahova and R. Manvyelov, the ensign of the prince S. Zhevahova, the exterior advisor Hersyevanov, the georgian prince George and others. Many georgians came to the sevice in the southern ukrainian military troops - the lieutenant prince I. Manvyelov, the second major prince $S$. Manvelov, the lieutenant S. Kahov.

The analysis of the materials of the First All-russia census allows us to confirm that the majority of the armenians-noblemen in Bessarabia lived in cities: in Ackerman - 20 persons, in Izmail - 40 persons, Reni - 1 person. In relation to the total number of the armenians who lived in these cities, the noblemen accounted for more than $7 \%$. The armenian community of the city Izmail was more aristocratic - more than $30 \%$ of its part, or every third person were noblemen.

Late of the XVIII - early of the XIX cent. the frenchmen, italians and greeks were fixed among the mass of the southern ukrainian nobility. Some of them went to Russia in search of the new opportunities to use their knowledge and skills, some for enrichment. Almost all of them settled in the south. Among the frenchmen, who left their trace in the history of the southern ukrainian provinces were the kamerts-advisor Ruv'ye (founder of the first merino sheepfolds in Crimea), the professor de Seppe (de Serres) scientist - engineer, botanist.

In Kherson in two years after its foundation there were the french trading company of the baron Antoine, which promoted the expansion of the trade relations of the city with France. Thanks to the french baron Antoine it was opened the new trade routes - on the Dnieper River to Ackerman and on the Bug to Ochakov.

In 1782, the founder of Kherson Ivan Abramovich Hannibal through the general Russian maritime commander the earl Motseniho received the letter from the italians, who wanted to move in the Russian empire and settle in Novorossiya - so began the wave of the italian migration to the southern ukrainian lands. Thus, the italian Amato in Novomoskovsk and Kherson districts of the vicegerency of Katerynoslav in the middle 80 -the of the XVIII cent. got
16.850 des. of the land, in Kherson district his fellow countyman the italian Vildin had 6.000 des. Land ${ }^{10}$. Among the famous landowners of the Southern Ukraine we meet also met the italian surnames - B. Hallero and Antonio Cornell. The italian aristocrats distinguished in the state service - in August 1816 the genoese nobleman Raphael Skass got the rank of the exterior adviser and was admitted to the staff of the State commission of the foreign affairs, as the bureaucrat by the special commission at the military governor of Kherson. The great Joseph de Ribas - mayor of Odesa - was born in Naples. Among his assistants - the native of Piedmont the second-major Vittorio Amadeo Poggio, who together with Neapolitan vice-consul Piero Skantsio signed the contract for the supply of the building materials from Italy. Many italian noblemen had the private houses in Odessa the second-major Smekio, the lieutenants de Pachiola, Savoyini, Sarachini, the colonel de Pelihrini, the captains Michelangelo Korsato and Beneddetto Radseto, the lieutenant Silistrio Del-Sasso ${ }^{11}$.

The second half of the XVIII cent. Includes the largest wave of the greek immigration to Russia. Among the greeks - settlers the craftsmen, workers, sailors and merchants made the majority in the southern ukrainian province. The greeks - representatives of the aristocratic families followed the greek volunteers to the ukrainian Black Sea land among other. One of the first on the lands of the Russian Empire were family Ipsilani, Katakazi, Muruzi, Negri and others who promoted the activization of the development of the economy, and partly also the political life of the region. The greek family Arkas linked the fate forever with Mykolaiv.

One of the main occupations of most greeks-colonists was trade, and, accordingly, some number of the prominent representatives of this ethnic group also combined in himself of the aristocratic origin belonging to the merchant's state. It is this combination was quite specific and defining feature of the greek aristocratic society of the region.

The noblemen as origin was a family of Dmitriy Spyrydonovych Inhlezi, who was born in Greece. The activity and the fate of the representatives of the ancient greek 
aristocratic family of Stameriv was related with Odessa. One of them - L. Stamer - was born and buried in Odessa, served in the chancery of the general - governor, the founder of the greek charities. In the late of the XIX cent. Alexander Arystydovych Revelioti - the greek, the nobleman, the bibliophile, known for his book collection, which is inherited from the father - Aristide Revelioti lived in Odessa. Among the famous greek - noblemen of the land it is necessary to name the families Rodokonaki, Marazli.

Among the greeks of Novorossiysk region constituted the significant part of the military men: Alopeus Fedor Davidovich - the general-lieutenant, the earl, mayor of Odessa; Liders Alexander Mykolayovych - the general-adjutant, the hero of the Crimean War; Popandopulo Alexander Spyrydonovych - the vice-admiral, the head of the port of Odessa; Radetsky Fedor Fedorovych. - the general from the infantry, the national hero of Bulgaria and Russia. All this clearly shows the gradual withdrawal of the greek nobyls from their roots and join the noble society.

According to the First All-russian census of 1897 almost 300 greeks - noblemen lived in the ukrainian Black Sea lands. The biggest number of the aristocratic Greek community lived in Khersons'ka province - more than 130 persons, although the relative density of the greek-noblemen was higher in Bessarabia in comparison with the total number of the nobility of the province. The smallest number of the representatives of the greek ethnic community was in Katerynoslavs'ka province.

The surnames of many greeks - the representatives of the aristocratic families associated with the construction of the municipal buildings, the churches, providing support for educational institutions and hospitals, the vigorous educational and charitable activities in the Black Sea region.

Interestingly, among the ethnic groups of three Black Sea provinces during the census of 1897 there are also quite "exotic" (for Southern Land). Thus, 27 noblemen-finns, 12 - swedes, and 1 nobleman - caucasian mountaineer lived in Khersons'ka province. 32 noblemen the native language called lithuanian-lettish and 9 noblemen - english in Katerynoslavs'ka province. For Bessarabia, here we find 10 noblemen the turkish-tatar origin, 7 noblemen - finns, 2 caucasian highlanders. Among the nobyls of the land were the swiss count Paravichini, the emirate nobleman Jam-Mambet-bay-Murza, the tatar families of Shiriniv, Mansursky, Arhynsky

A characteristic feature of the southern ukrainian nobility was its multi-ethnic structure, which had no analogues in the world. However, it does not stir class and social unity of this stratum. The presence of the mass of the nobility the significant estate of the representatives of the different european language groups - german, french, italian, greek, moldovan - shows on the one hand, their direct participation in the processes of the development of the southern ukrainian lands, and on the other - about the loyalty of the imperial power to them. While on the other hand, the facts testify, that the majority of the hereditary and personal noblemen belonged to the indigenous population and only the small part of them - to the number of those who were born in other countries.

As aptly noticed the researcher $\mathrm{D}$. Bagaley, “... it is not necessary to judge strictly the colonists of the southern ukrainian lands. Some of them have done more, others - less. Much has been made good, outstanding, useful. There were not also outstanding, evil. Some like to serve the public interest, others simply do their duty, others sought glory, while others abandoned their benefit. But eventually the work was great: Novorossiysk region was got by the arms and the peaceful settling and planted it in a piece of culture" ${ }^{\prime 2}$. Without prejudice to the contribution of the foreigners in the process of the colonization of the region, we believe that the main burden as to the development of the southern ukrainian lands, their political-administrative arrangement laid on the shoulders of the representatives of the traditional for these lands of the ethnic groups - ukrainian, russians, poles, moldavians.

\section{ЛІТЕРАТУРА:}

${ }^{1}$ Багалий Д.И. Очерки из истории колонизации и быта степных окраин Московского государства / Д.И. Багалий - М.: Типография университета, 1887. - Т.1. - С.527 - 528.

${ }^{2}$ Скальковский А. А. Опыт статистического описания Новороссийского края и Бессара- 
бии: [в 2 ч.] / А.А.Скальковский. - Одесса: Типография Л. Нитче, 1850. - Т.1.(География, этнография, народонаселение Новороссийского края). -366 с. - С. 253.

${ }^{3}$ Інститут рукопису Національної бібліотеки ім. В. Вернадського НАН України (Далі IP НБУ) - Ф. 42. - Спр. 276. Подборка копий документов о развиитии помещичьего хозяйства и промышленности в 1780-1800 гг. в Новороссии. Часть II.- Арк. 73

${ }^{4}$ Boyarynashi (minor nobles) - bore the internal service at the court. Their ranks replenished not only the natives from the boyars, but also among the simple people. This is the small landowners, who at one time for certain services received the right of personal nobility from the moldovian hosts.

${ }^{5}$ IP НБУ - V.925. Постановление депутатов дворянства, духовенства Бессарабии о создании комитета 12 для утверждения молдавских прав, привелегий и обычаев. 1815 г. (рукопись). -3 арк.

${ }^{6}$ Алфавитный список дворянским родам Бессарабской губернии, внесенным в дворянскую родословную книгу по 1-е января 1911 года. - Кишинев, 1912. - 48 с.

${ }^{7}$ Некрополі України: Колективна монографія, присвячена історії некрополів. - К.: Укр.тов.охорони пам. іст та культ., 1999.- 287 c. - C. $44,67,89$.

${ }^{8}$ Беккер С. Миф о русском дворянстве. Дворянство и привилегии последнего периода императорской России / Nobility and Privilege in Late Imperial Russia/ Сеймур Беккер. - Режим доступу: http://wg-lj.livejournal.com.

9 Первая всеобщая перепись населения Российской империи 1897 г. ...- Т. 47: Херсонская губерния. - 1904. - [6], XVI, 319 с.

10 Дружинина Е.И. Северное Причерноморье. 1775 - 1800 гг./ Елена Иоасафовна Дружинина. - М.: Изд-во АН СССР, 1959. 279 c. - C. $162-163$.

11 Бацак К.Ю. Італійська еміграція в Україні: джерела та шляхи формування, міжнародні зв'язки (80-ті роки XVIII- перша третина XIX ст.): дис... канд. іст. наук: 07.00.02/ Костянтин Юрійович Бацак К.,1999. - 142c.

${ }^{12}$ Багалій Д.І. Заселення Південної України (Запоріжжя й Новоросійського краю) і перші початки іiі культурного розвитку/ Д.І.Багалій. Х.: Вид-во “Союз" Харк. кредит. союзу кооперативів, 1920. - 102 с. - С. 60-61. Етнічна структура дворянства Півдня України (кінеиь XVIII - XIX cm.) (2)

\section{Циганенко Лілія. ЕТНІЧНА СТРУКТУ- РА ДВОРЯНСТВА ПІВДНЯ УКРАЇНИ (КIНЕЦЬ XVIII - XIX CT.) (2)}

В статті аналізується етнічний склад дворянства Катеринославської, Херсонської та Бессарабської губерній; участь аристократів українського, російського, молдавського, грецького, німецького, італійського походження у процесах колонізації та освоєння південноукраїнських земель Російської імперії впродовж кінця XVIII- XIX ст.

Автор дослідження висловлює думку про три хвилі міграції молдавського етносу до українських провінцій в XVIII столітті. Перша хвиля переселень представників молдавського етносу була пов'язана 3 провалом Прутського походу під командуванням Петра I в 1711 році, коли російська нація прийняла 24 сім'ї бояр 3 молдавським господарем Д. Кантемиром. Їх поселення були в основному на Слобожанщині, де вони отримали 710 подвір'їв.

3 середини XVIII ст. почалася друга хвиля молдавської міграції на південні українські землі, до якої були безпосередньо залучені також представники молдавських бояр. Таким чином, в 1752 році молдавський боярин Манолакій Замфіракович служив в Новій Сербії. Лейтенант М. Фухаров, полковий комісар П. Вітер служили в Словяносербії. За словами А. Скалковського, в 1753 Василь Звєрєв, молдаванин за походженням, чиє справжнє ім'я було Василе Лупул, брав активну участь у створенні Новокозачого полку, охопивши більше тисячі селян у південних українських земель, 3 яких були сформовані компаній військово-сільськогосподарські поселення.

Третя хвиля міграції молдавських бояр відбулася в 90-ті роки XVIII ст. коли Росія готувалася приєднати Бессарабію, і заохочувала жити на своїй території.

Наприкінці XVIII ст. серед землевласників Катеринославської губернії було чимало представників молдавської аристократії власник Rosseti, фактичний таємний радник князя Kantakuzino, князь Pervula Kantakuzino, Принцеса Roksandry Hiku, генерал-майор В. Звєрєв (Лупул). У той же час в Тирасполі було двадцять шість молдавських боярів. Загальна площа землі, відданої їм склала 251,535 га. Після 1812 р. потік молдавських мігрантів до Катеринославської і Херсонської провінцій обмілів. Це сталося значною мірою через включення Бессарабії до складу Російської імперії. Як влучно зауважив дослідник Д. Багалій, «... не треба судити строго колоністів південних українських земель. Деякі 3 них зробили більше, інші - менше. Багато чого було 
зроблено добре і корисно. Там не було якогось надзвичайного зла. Деякі прагнули служити громадським інтересам, інші просто виконували свій обов'язок, ще дехто прагнув слави, в той час як хтось відмовився від своєї користі. Але врешті-решт робота була пророблена велика: Новоросійський регіон був у руках мирного населення і зростав культурно».

Не применшуючи внеску іноземців в процесі колонізації регіону, вважаємо, що основне навантаження щодо розвитку південних українських земель, їх політико-адміністративний устрій лягло на плечі представників традиційних для цих земель етнічних груп українських, російських, поляків і молдаванів.

Ключові слова: дворянство, колонізація, загальноросійський перепис, етнічні групи, аристократи, шляхетство. 